\title{
Where Do the Children of Professors Attend College?
}

\author{
by
}

John J. Siegfried and Malcolm Getz

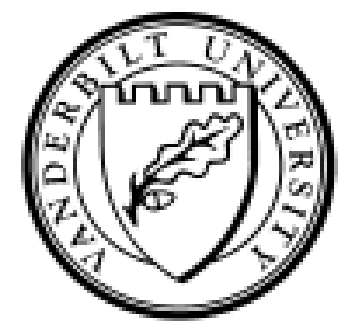

Working Paper No. 03-W02

February 2003

\section{DEPARTMENT OF ECONOMICS}

VANDERBILT UNIVERSITY

NASHVILLE, TN 37235

www.vanderbilt.edu/econ 


\title{
Where Do the Children of Professors Attend College?
}

\author{
John J. Siegfried \\ Malcolm Getz \\ Vanderbilt University \\ Box 351819 \\ Nashville, Tennessee 37235 \\ John.J.Siegfried@vanderbilt.edu \\ Malcolm.Getz@vanderbilt.edu
}

FAX 615-343-8495

\begin{abstract}
To ask whether the best-informed consumers of higher education, the faculty, make different choices than other similarly endowed consumers, we compare the pattern of colleges chosen by 5,592 children of college and university faculty with the pattern chosen by the children of non-faculty families of similar socio-economic status. The patterns are remarkably different. The children of faculty are more likely to choose research universities and even more likely to choose selective liberal arts colleges. This evidence is consistent with the view that the level of information makes a difference in the choice of college.
\end{abstract}

February 10, 2003 
We owe great thanks to the many staff members of the colleges and universities who provided information about their tuition remission programs. We appreciate the use of data from the National Education Longitudinal Survey. Sheldon Steele, Martha Bailey, and Mary Hwang helped process data for this study. The Atlantic Philanthropic Services Corporation provided financial support. Ronald Ehrenberg, Daniel Hammermesh, W. Lee Hansen, and colleagues at Vanderbilt provided helpful comments on an earlier draft. 


\section{Where Do the Children of Professors Attend College?}

People often choose a college based on reputation. Consequently, as a university's national ranking grows, it typically enjoys a substantial increase in applications. (Monks and Ehrenberg, 1999) When athletic teams appear in prominent televised contests, applications often rise. When asked what sells, the Dean of Admissions at one research university said "Research." "Universities respond with measures to enhance their place in national rankings, including higher subsidies for prime-time athletics and more research.

Such efforts may diminish the quality of educational services delivered to undergraduates. The emphasis on graduate education and research causes one prominent research university to have 40 percent of its undergraduate instruction conducted by graduate students and another 30 percent by adjunct faculty. ${ }^{2}$ Another recently announced a plan to "allow its senior faculty to be eligible for a paid sabbatical term after each six terms in residence (rather than the current twelve)" undoubtedly leaving fewer undergraduate courses staffed by the senior faculty. ${ }^{3}$ With an emphasis on national rankings that seems to be driven in part by research accomplishments, many universities offer little reward to faculty who are successful teachers. As an institution's emphasis on research expands, undergraduates can expect to have less contact with

\footnotetext{
${ }^{1}$ William Shain as reported in the Minutes of the Arts and Science Faculty Council, Vanderbilt University, October 1, 2002.

${ }^{2}$ Kim Phillips-Fein, "Yale Bites Unions for God, Country, and the Ruling Class," The Nation, July 2, 2001 p. 12,

${ }^{3}$ Jeremy R. Knowles, Dean of the Faculty of Arts and Science, Harvard University, Annual Letter, February 1, 2002. p. 5 .
} 
those faculty who generate the university's reputation and are likely to find faculty focused on research rather than on undergraduates' instructional needs.

Robert Zemsky and William Massy, et al. [1999] have argued that "too many educational consumers [are] bad shoppers: too quick to mistake prestige for quality." College shoppers often buy at very high prices the "right kind of company — smart, accomplished, likely to succeed - as well as the right kind of education." In Zemsky and Massy's view, the purchase of prestige and elite peers by college bound students and their families illustrates a market failure. The market where students choose colleges fails because of an information deficiency - the decision-makers simply do not know enough about just what colleges can contribute. Consequently, there is the "potential for supplying the kind of consumer information - as in an education Consumer Reports - that would allow applicants to base their college choices on something more than the prestige of the institution and the competitive quality of its students." [Robert Zemsky and William Massy, et al., 1999]

Zemsky and Massy argue that those high school seniors who will attend college and their families are disadvantaged by a lack of information when selecting among alternative institutions. If college consumers understood how much they pay just for prestige and just for the opportunity to associate with other elite students that accompanies admission to expensive selective colleges and universities, they would make different choices. The consequences of such different choices would be less demand for prestige and for elite peers, thereby pressuring research universities that subsidize graduate programs and faculty research with undergraduate tuition instead, to devote relatively more resources to undergraduate instruction. 
Zemsky and Massy's characterization of college choices implies both that more knowledgeable consumers of college education make different decisions than less knowledgeable consumers, and, also, that knowledgeable consumers place less emphasis on prestige and more on the quality of educational services delivered. Both propositions are testable.

If differences in college choices are observed, then the second question - which set of choices is "better"- becomes relevant. Only if there are both differences between the choices and the choices are "better" when made by the knowledgeable consumers " is there reason to consider a Consumer Reports for prospective college students.

There are two groups of highly selective institutions. Research universities emphasize graduate and professional programs and faculty research in addition to undergraduate programs. Selective liberal arts colleges focus on undergraduate programs. It is possible that informed consumers choose highly selective institutions for peer effects but differ in choosing research universities versus liberal arts colleges because of differences in emphasis on undergraduate education versus differences in national reputations and prestige. Most leading research universities have strong national reputations, while only a very few elite liberal arts colleges are well known outside their geographic region.

Using original data we collected, we compare the pattern of colleges chosen by the children of college and university faculty with the pattern chosen by children who grew up in non-faculty families of similar socio-demographic status. The purpose is to ask whether better informed consumers of higher education make different choices than other similarly endowed consumers, assuming that households containing a college or university faculty member are better informed. There is substantial evidence that the 
patterns differ. The children of faculty are much more likely to choose research universities and selective liberal arts colleges.

We gathered data on the college attended by the children of faculty and of staff at 25 colleges and universities that have completely portable tuition remission fringe benefit programs for faculty and staff dependents. The data refer to the first college attended by the faculty and staff children within the period 1992 to 2002. They reflect choices among colleges usually made during the child's senior year in high school. Our sample is described in Table 1. About ten percent of the children enrolled at the college or university where one of their parents is employed.

Table 1. Count of Children Reporting College Attended: Data from Faculty and Staff at 25 Colleges and Universities

\begin{tabular}{lrrrr}
\hline Children of: & All & $\begin{array}{c}\text { Attended } \\
\text { Own School }\end{array}$ & $\begin{array}{c}\text { Percent Own } \\
\text { School }\end{array}$ & $\begin{array}{c}\text { Net of Own } \\
\text { School }\end{array}$ \\
\hline Faculty & 5,592 & 850 & $15.2 \%$ & 4,742 \\
Staff & 11,347 & 970 & 8.5 & 10,377 \\
\hline Total & 16,939 & 1820 & 10.7 & 15,119 \\
\hline
\end{tabular}

We use the National Education Longitudinal Survey (NELS) from the National Center for Education Statistics as a benchmark. This survey contacted 25,000 eighth graders in 1988, with follow-up interviews in 1994. It identifies college attended and parental education, income, and occupation. The restricted-use NELS data allow us to identify the college attended by each student and to classify those colleges using the system developed by the Carnegie Foundation for the Advancement of Teaching. We then compare the pattern of colleges as defined by Carnegie Classification chosen by the children of college and university faculty and by college and university staff with the pattern chosen by children in families not employed in higher education, stratified by income, parental education, and occupation. 
The goal is to observe whether more knowledgeable consumers make college and university choices that differ from those made by less knowledgeable consumers. The basic proposition is that children of college and university faculty and staff have access to more and better information about differences among types of colleges and universities and among different institutions than do children from non-academic families with comparable incomes, occupations, and parental education. This is a straight-forward extrapolation of the observation that children of parents with a college education have a source of information to aid in their choice that is unavailable to children in families where neither parent attended college [Ceja, 2000; Basten, Cole, Maestas, and Mason, 1997]. When combined with the finding from the college choice literature that parents are critical to the decision-making process [Moogan, Baron, and Harris, 1999; Baleman and Kennedy, 1999; Hossler and Stage, 1987], the access of parents to more and better information sets up a reasonable test of Zemsky and Massy's contention that college choices are suboptimal as a result of ignorance. Manski and Wise's [1983] careful study of college choice using a national sample showed that SAT score, high school class rank, parents' income, and the level of parents' education strongly influence a student's probability of applying to college, of being accepted and attending, and of completing a degree program. Manski and Wise found that when students have a choice, they tend to choose colleges with average SAT scores about 100 points above their individual scores, but are not very likely to choose a college with a mean SAT score more than 100 points higher than their own score. Long [2003] also finds that students are more likely to select a college with average SAT scores higher than their own. She discovered, moreover, an upward trend in the likelihood of selecting a college with higher average SAT scores. Nevertheless, the choice of college usually is based on more than a simple hierarchy described by the mean test scores of entering 
classes. A student may value many dimensions of colleges in addition to net price and average test scores. Among other important considerations is his or her expected class rank, which is undoubtedly correlated negatively with the academic competitiveness of the college selected.

\section{Survey of Colleges with Tuition Benefits}

We asked colleges that provide a portable tuition remission benefit to the children of their faculty to report to us the name of the first college entered by each such child. We have limited the survey to colleges and universities where the tuition remission benefit may be used at any accredited institution of higher education. ${ }^{4}$ Children of employees at such institutions are unconstrained in their choice of college. Thus, the pattern of their choices can be compared to that of other college students from families with similar incomes and backgrounds.

The tuition benefit plans create an income effect. At some of the institutions where the benefit is available to all employees, the tuition remission is excluded from taxable income, further expanding the income effect. We believe that with the income effect the children of these college and university faculty, mostly full professors at well-paying institutions by the time their offspring graduate from high school, have sufficient

\footnotetext{
${ }^{4}$ Many colleges participate in Tuition Exchange and other consortia wherein tuition is subsidized when a student attends a college in the consortium. One research university in our survey limits the benefit to four-year colleges and universities. The universities in our survey are: Brown, Carnegie Mellon, Clark, Cornell, Johns Hopkins, MIT, Vanderbilt, Washington University, and Yale. In Carnegie Classification of 2000, Clark is a Doctoral/Research University - Intensive, the others are Doctoral/Research Universities - Extensive. We refer to all as "Research universities." The selective Liberal Arts colleges are all Baccalaureate Colleges - Liberal Arts in the Carnegie Classification: Amherst, Bryn Mawr, Claremont McKenna, Colby, Davidson, Gettysburg, Hamilton, Lafayette, Middlebury, Pomona, Smith, Swarthmore, Trinity, Union, Wesleyan, and Williams.
} 
financial resources to attend virtually any college or university. Furthermore, prior research suggests that cost considerations do not play a dominant role in the choice of colleges made by most upper-income students [Paulson and St. John, 2002] or by students with relatively high SAT scores [Long, 2003]. The tuition benefit also creates a price effect because the benefit is related to the size of tuition and so diminishes price differentials. ${ }^{5}$ Because of eligibility criteria, tuition benefit programs may reduce turnover among faculty and staff, just as do deferred compensation and college benefit programs offered to employees by many employers. [Capelli, 2002]

Often colleges and universities offer a larger tuition remission benefit on their own campus than elsewhere, and thus the choice of attending the parent's employer is not on an equal footing with others. ${ }^{6}$ Therefore, we exclude students attending their "home institution" from most of our analysis. Those attending their home college constitute about ten percent of the students in the sample. We report here an analysis using the 25 colleges and universities from which we received data. ${ }^{7}$ All of the colleges and universities in the survey are private institutions. Indeed, a fully portable tuition remission benefit is probably only available at private institutions. This characteristic of our sample may bias some of the college choices, because employees of private colleges and universities may have a preference toward the private sector and transmit this

\footnotetext{
${ }^{5}$ Some tuition remission benefits are defined as a percentage of tuition up to a maximum of that same percent of the home institution's tuition. The Hamilton College benefit is typical. Employees who have worked at the College for at least three years may receive 50 percent of the tuition of the institution the child attends, up to a maximum of 50 percent of Hamilton's tuition. See Appendix A for a summary of the tuition benefit plans.

${ }^{6}$ This differential is often defended by arguing that the marginal cost of an additional student is less than tuition. The argument makes little sense, however, for selective institutions because the employee's child would displace a full-paying (or at least full-paying less expected financial aid) student who otherwise would be admitted and attend. All 25 colleges and universities in our sample are selective.
} 
attitude to their children. If the children select private institutions more frequently than children in otherwise comparable non-faculty families, the distribution across the Carnegie Classifications will be affected because institutions in the Research and Doctoral Extensive and Liberal Arts categories are disproportionately private.

We compare the pattern of colleges attended using the classification of colleges and universities in use by the Carnegie Foundation for the Advancement of Teaching in $2000{ }^{8}$ Statistical tests are conducted using contingency tables at a one-percent level of significance. The p-values on all the chi-square tests reported are less than one percent. We report tests of proportions reflecting college choices among eight categories of colleges to allow the fullest set of choices. However, the decision to attend a four-year college versus a two-year college may be quite different than the choice among fouryear colleges. Therefore, we also test the similarity of patterns among just the six regular four-year college categories, and get similar results. Ultimately, our focus is on the choice between the most selective Research and Doctoral Extensive (called Research Extensive in the tables) and Baccalaureate I (Liberal Arts in the table), and other fouryear colleges and universities. The latter category includes Research and Doctoral Intensive (called Doctoral in the tables). Therefore, we also test the proportions choosing

\footnotetext{
${ }^{7}$ Six colleges and universities with fully portable tuition benefits for the children of faculty declined the opportunity to participate in our study. We estimate that there are about 40 colleges and universities that provide their employees with a fully portable generous tuition remission fringe benefit.

${ }^{8}$ http://www.carnegiefoundation.org/Classification/index.htm Carnegie Foundation for the Advancement of Teaching. We use the 2000 classification, the latest system. The primary criterion for identifying Baccalaureate Colleges - liberal arts in the Carnegie classification is the proportion of undergraduate degrees awarded in the liberal arts (vis-à-vis professional programs). A minimum of 50 percent is required to qualify for the Liberal Arts category. The Baccalaureate Colleges - General category has less than half of their graduates in the liberal arts. We group the small baccalaureate/associate category with the associate colleges. The various special colleges are grouped as "other". The Doctoral/Research Universities - Extensive label is abbreviated here to Research Extensive and the Doctoral/Research Universities - Intensive label is abbreviated here to "Doctoral."
} 
among just these three categories, again obtaining similar results. The alternate tests are reported in Appendix C.

When respondents report the colleges attended by the children of administrators separately (nine did this), we have excluded them. Some colleges include the children of administrators among the faculty data and some among the staff data. We exclude from our analysis those children who attend the institution where their parents are employed because that choice may be especially favored or disfavored for several reasons, including cost, distance, convenience, and familiarity. We also exclude those who attend institutions outside the United States or for which we are otherwise unable to identify a Carnegie Classification for the college. The foreign and unidentified institutions account for less than one percent of the total.

Table 2. Faculty versus Staff Children (25 Colleges and Universities)

\begin{tabular}{lrcrcrr}
\hline \multicolumn{1}{c}{$\begin{array}{c}\text { Students' } \\
\text { Carnegie } \\
\text { Classification }\end{array}$} & Faculty & \multicolumn{5}{c}{ Staff } \\
nyyyyyy & & percent & & percent & All & percent \\
\hline Research Extensive & 2,186 & $46.1 \%$ & 2,847 & $27.4 \%$ & 5,033 & $33.3 \%$ \\
Doctoral & 298 & 6.3 & 1,097 & 10.6 & 1,395 & 9.2 \\
Master's I & 495 & 10.4 & 2,662 & 25.7 & 3,157 & 20.9 \\
Master's II & 60 & 1.3 & 281 & 2.7 & 341 & 2.3 \\
Liberal Arts & 1,327 & 28.0 & 1,197 & 11.5 & 2,524 & 16.7 \\
BA General & 91 & 1.9 & 392 & 3.8 & 483 & 3.2 \\
Associate & 147 & 3.1 & 1,574 & 15.2 & 1,721 & 11.4 \\
Other & 138 & 2.9 & 327 & 3.2 & 465 & 3.1 \\
\hline Total & 4,742 & 100.0 & 10,377 & 100.0 & 15,119 & 100.0 \\
\hline
\end{tabular}

Source: Authors' survey. Chi-square 1,775.93; critical chi-square $(0.01,7)=18.48$. 
The pattern of colleges selected by the children of faculty is compared with that resulting from the choices of the children of staff at our 25 responding colleges and universities in Table 2. The 4,742 children of faculty include 3,607 children of Research university faculty and 1,135 children of selective Liberal Arts college faculty. A chisquare test rejects the hypothesis that the pattern is the same for faculty and staff children. ${ }^{9}$ The children of faculty are much more likely to choose a Research Extensive university or a selective Liberal Arts college. Forty-six percent of faculty children enter a Research Extensive university and 28 percent enter a Liberal Arts college compared with 27.4 and 11.5 percent for the children of staff at the same institutions. The children of staff are more likely to attend a Doctoral, Master's, or Associate (two-year) college. This is an expected result given the likely difference in average income, education, and information about colleges and universities available to college faculty versus staff. This comparison illustrates the importance to our analysis of using, as a benchmark, a national survey of households that identifies the occupation, income, and education level of parents.

Even without staff children in our sample, however, the importance of controlling for the socio-demographic backgrounds of families is apparent from the literature on college choice. Parents' education levels affect college choices. [Ceja, 2000; Rouse, 1994; Litten, 1985, Basten, Cole, Maestas, and Mason, 1997] Higher levels of parents' education seem to be associated with an inclination toward private colleges and

\footnotetext{
9 The choices of children of administrators are included in the "All" column in the table but are excluded from the contingency table analysis. The chi-square test reported here compares the pattern of colleges chosen across the eight categories shown in the table at a significance level of 0.01 . See Appendix $\mathrm{C}$ for a test of colleges excluding the "Associate" and "Other" categories and for a test of Research Extensive Universities and Liberal Arts Colleges as two categories against the other four regular four-year college and university categories combined into a single group. All of the chi-square tests of independence are statistically significant at the one percent level.
} 
universities. [Litten, 1983] Well-educated parents may also encourage their children to attend highly selective institutions because such enrollment signals social prestige. [Basten, Cole, Maestas, and Mason, 1997; Ihlanfeldt, 1980] Some studies find that the parents' occupation matters [King, 1996] while others do not. [Basten, Cole, Maestas, and Mason, 1997] It appears that holding many other things constant, children of academically employed parents are more likely than their peers to consider selective liberal arts colleges [Litten, 1985]

The conventional wisdom regarding the effect of family income on college choice is also mixed. Spies [1978] found that the probability of applying to a more selective college or university increases moderately with family income, which is consistent with Cabrera and La Nasa's [2000] discovery that income is moderately correlated with the choice of a university over other four-year institutions. In a study of where New Hampshire college-bound students apply, however, Toutkoushian [2001] found that high school seniors from lower income families did not make dramatically different choices than other students. Many New Hampshire students from low-income families applied to expensive selective institutions, apparently well informed about need-based financial aid opportunities.

Our survey of colleges and universities elicited responses from 16 selective Liberal Arts colleges and nine Research universities. Table 3 compares the pattern of choice of college by children of faculty employed by selective Liberal Arts colleges to those whose parents teach at Research universities. 
Table 3. College Choice by Faculty Children for Selective Liberal Arts versus Research University Faculty

\begin{tabular}{|c|c|c|c|c|c|c|}
\hline \multirow{2}{*}{$\begin{array}{c}\text { Students' } \\
\text { Carnegie } \\
\text { Classification } \\
\end{array}$} & \multicolumn{6}{|c|}{ Parents' Classification } \\
\hline & $\begin{array}{l}\text { Research } \\
\text { University }\end{array}$ & percent & $\begin{array}{c}\text { Liberal } \\
\text { Arts }\end{array}$ & percent & Total & percent \\
\hline Research Extensive & 1,826 & $50.6 \%$ & 360 & $31.7 \%$ & 2,186 & $46.1 \%$ \\
\hline Doctoral & 226 & 6.3 & 72 & 6.3 & 298 & 6.3 \\
\hline Master's I & 416 & 11.5 & 79 & 7.0 & 495 & 10.4 \\
\hline Master's II & 44 & 1.2 & 16 & 1.4 & 60 & 1.3 \\
\hline Liberal Arts & 831 & 23.0 & 496 & 43.7 & 1,327 & 28.0 \\
\hline BA General & 55 & 1.5 & 36 & 3.2 & 91 & 1.9 \\
\hline Associate & 115 & 3.2 & 32 & 2.8 & 147 & 3.1 \\
\hline Other & 94 & 2.6 & 44 & 3.9 & 138 & 2.9 \\
\hline Total & 3,607 & 100.0 & 1,135 & 100.0 & 4,742 & 100.0 \\
\hline
\end{tabular}

Source: Authors' survey. Test chi-square $=233.57$; critical chi-square $(0.01,7)=$ 18.48. See Appendix C for alternate tests.

A chi-square contingency test comparing the proportions of children of faculty from selective Liberal Arts colleges to the proportions of children of faculty from Research universities attending each classification of colleges rejects the hypothesis that they are the same. Even after excluding those who attend the institutions that employ a parent, the children of Research university faculty are more likely to attend Research Extensive universities than any other type of college. And, even after excluding those who attend the institutions that employ a parent, the children of selective Liberal Arts college faculty are more likely to attend Liberal Arts and Baccalaureate General colleges but less likely to attend any other groups of colleges than the children of Research university faculty. The differences are remarkable. About 44 percent of the children of selective 
Liberal Arts college faculty enroll at a selective Liberal Arts college compared with 23

percent of the children of Research university faculty. ${ }^{10}$

\section{Comparison By Household Income}

In order to compare the college choices made by the children of faculty with the choices made by children in financially similar, generally non-academic, households, we use the National Education Longitudinal Survey 1988 (NELS). ${ }^{11}$ The 1994 follow-up NELS survey reveals the first college attended by those who still participated in the survey. Table 4 summarizes the pattern of college choice nationally. We have usable responses from 14,917 persons. ${ }^{12}$ Among these, 8,900 entered college by 1994, 59.7 percent of the sample. By matching the institution code in NELS with its Carnegie Classification, we successfully identified the college attended by 7,856 of the NELS respondents. The other 1,044 did not report the college attended.

To compare the national data with the choices of children of college and university faculty, we categorize household income as shown along the top margin of Table 4 . NELS reports 1991 household incomes in categories. Our income divisions are at $\$ 25,000, \$ 35,000, \$ 50,000$, and $\$ 100,000$. Median household income in 1991 for the U.S. was $\$ 31,962$. Information about income was missing from 3,391 of the NELS

\footnotetext{
${ }^{10}$ If we include students who attend the institutions where a parent is on the faculty, the percentage of faculty children attending Liberal Arts colleges is 48.6 percent among the children of selective Liberal Arts college faculty and attending a Research Extensive university is 74.1 percent of the children of Research university faculty.

${ }^{11}$ NELS does not identify sufficiently detailed occupations to allow us to exclude academic households. Therefore, the NELS set includes academic and non-academic households.

${ }^{12}$ The 14,917 reflect weighting responses so that the results are representative of the nation. NELS oversampled minority groups. Therefore, it is necessary to weight the raw data to reflect the nation as a whole.
} 
respondents. The salaries of full professors at private colleges averaged $\$ 61,600$ in 1991. ${ }^{13}$ Including the value of a 50 percent tuition remission fringe benefit when tuition is $\$ 20,000$ would increase this to about $\$ 71,000$ for 1991 . When the benefit is exempt from taxation, the before tax equivalent income is about $\$ 76,000$. The average income of the parents of NELS respondents who attended regular four-year colleges was $\$ 62,595$.

Table 4. College Choice by 1991 Income from NELS 88 (percentage distribution)

\begin{tabular}{|c|c|c|c|c|c|c|c|}
\hline \multirow{2}{*}{$\begin{array}{c}\text { Students' } \\
\text { Carnegie } \\
\text { Classification }\end{array}$} & \multicolumn{7}{|c|}{ Parents' Income Levels } \\
\hline & $\begin{array}{l}\text { Under } \\
\$ 25 K\end{array}$ & $\begin{array}{c}\$ 25 K \\
\text { to } \\
\$ 35 K \\
\end{array}$ & $\begin{array}{c}\$ 35 K \text { to } \\
\$ 50 K\end{array}$ & $\begin{array}{c}\$ 50 K \text { to } \\
\$ 100 K\end{array}$ & $\begin{array}{c}\text { Over } \\
\$ 100 \mathrm{~K}\end{array}$ & Total & $\begin{array}{c}\text { Mean } \\
\text { Income, } \\
\text { Approximate }\end{array}$ \\
\hline Total Count & 1,542 & 864 & 1,392 & 2,204 & 608 & 6,610 & \\
\hline Research Extensive & $14.6 \%$ & $13.4 \%$ & $17.3 \%$ & $24.9 \%$ & $42.2 \%$ & $21.0 \%$ & $\$ 73,609$ \\
\hline Doctoral & 5.6 & 7.3 & 7.3 & 6.8 & 8.5 & 6.9 & $\$ 57,961$ \\
\hline Master's I & 19.6 & 19.5 & 20.7 & 21.3 & 13.5 & 19.8 & $\$ 49,572$ \\
\hline Master's II & 1.9 & 2.3 & 2.6 & 2.7 & 2.0 & 2.4 & $\$ 52,083$ \\
\hline Liberal Arts & 2.5 & 2.9 & 4.4 & 5.8 & 14.0 & 5.1 & $\$ 83,441$ \\
\hline BA General & 5.5 & 5.5 & 5.0 & 3.2 & 4.4 & 4.5 & $\$ 47,216$ \\
\hline Associate & 47.8 & 47.3 & 41.1 & 33.6 & 13.4 & 38.4 & $\$ 41,714$ \\
\hline Other & 2.3 & 1.9 & 1.6 & 1.7 & 2.0 & 1.9 & $\$ 38,703$ \\
\hline \multirow[t]{2}{*}{ Total } & & & & & & & $\$ 51,068$ \\
\hline & 100.0 & 100.0 & 100.0 & 100.0 & 100.0 & 100.0 & \\
\hline
\end{tabular}

Source: Authors' calculation from the National Education Longitudinal Survey 1988, National Center for Education Statistics. College entrance was in 1992 or 1993. NELS reports income by ranges. The mean income here is approximate, assigning the midpoint of the range to each individual, and using $\$ 225,000$ for the top category.

The percentage of children from households of each income category attending each of the Carnegie groups of colleges and universities is reported in Table 4. The table shows

\footnotetext{
${ }^{13}$ Statistical Abstract of the United States, 1992 table 271, reporting data from the American Association of University Professors.
} 
a strong shift toward Research universities and Liberal Arts colleges as household income rises. Indeed, a student from a family in the top income group (income over $\$ 100,000)$ in the table is nearly three times more likely to attend a Research Extensive university and more than five times as likely to attend a selective Liberal Arts college as a student from a family in the under $\$ 25,000$ income group. Although the literature on college choice does not assign a priority role to income as a determinant of college attendance after holding other family background characteristics constant, it appears that income may be very important in the choice among types of colleges.

Table 5. Comparison of College Choices in NELS Households with 1991 Income over \$50,000 to College Choices of Research University Faculty and Selective Liberal Arts Faculty Households

\begin{tabular}{lrrrrrr}
\hline \multicolumn{1}{c}{$\begin{array}{c}\text { Students } \\
\text { Carnegie } \\
\text { Classification }\end{array}$} & \begin{tabular}{c} 
NELS \\
Income over \\
\cline { 2 - 7 }
\end{tabular} & \multicolumn{4}{c}{$\begin{array}{c}\text { Research } \\
\text { University }\end{array}$} & \multicolumn{3}{c}{$\begin{array}{c}\text { Liberal } \\
\text { Arts } \\
\text { (100K }\end{array}$} & percent & Faculty & percent & Faculty & percent \\
\hline Research Extensive & 257 & $42.2 \%$ & 1,826 & $50.6 \%$ & 360 & $31.7 \%$ \\
Doctoral & 52 & 8.5 & 226 & 6.3 & 72 & 6.3 \\
Master's I & 82 & 13.5 & 416 & 11.5 & 79 & 7.0 \\
Master's II & 12 & 2.0 & 44 & 1.2 & 16 & 1.4 \\
Liberal Arts & 85 & 14.0 & 831 & 23.0 & 496 & 43.7 \\
BA General & 27 & 4.4 & 55 & 1.5 & 36 & 3.2 \\
Associate & 82 & 13.4 & 115 & 3.2 & 32 & 2.8 \\
Other & 12 & 2.0 & 94 & 2.6 & 44 & 3.9
\end{tabular}




\begin{tabular}{lllllll}
\hline Total & 608 & 100.0 & 3,607 & 100.0 & 1,135 & 100.0 \\
\hline
\end{tabular}

Source: Authors' survey and NELS 88. Test chi-square $=174.57$ for Research university faculty children; critical chi-square $(0.01,7)=18.48$. An additional 741 children of Research university faculty attended the university where a parent is on the faculty. Test chi-square for selective Liberal Arts college faculty children $=213.13$; critical chi-square $(0.01,7)=18.48$. An additional 109 children of Liberal Arts college faculty attend the college where a parent is a faculty member.

In Table 5, the pattern of college choice for children of Research university and selective Liberal Arts college faculty from our survey is compared with the college choices of children of non-academic households with 1991 income over $\$ 100,000$. A chi-square test firmly rejects the null hypothesis that the distribution across Carnegie classifications is the same. The children of Research university faculty are much more likely to attend Research Extensive universities and Liberal Arts colleges, and much less likely to attend Master's I and Associate degree colleges than are the children of non-academic households with 1991 income over $\$ 100,000$. The differences are substantial. The child of a Research university faculty member is 20 percent more likely to enter a Research Extensive university and 64 percent more likely to enter a selective Liberal Arts college than a child from an average non-academic family in the top income group. The Research university child is moderately less likely to enter a Master's I university and dramatically less likely to enter an Associate degree college as is an average child from a non-academic family in the top income group.

Using the last two columns of Table 5, we also compare the pattern of college choice for children of selective Liberal Arts college faculty from our survey with the college choices of children of non-academic households with 1991 income exceeding \$100,000. A chi-square test rejects the null hypothesis that the proportions of colleges attended are the same for the children of selective Liberal Arts college faculty as for children from 
non-academic families in the top income group. The children of Liberal Arts college faculty are nearly three times more likely to attend Liberal Arts colleges (other than the one where their parent works) than are children of non-academic households with incomes in the top income group. They are only about half as likely to attend a Master's university and about one-fifth as likely to enter an Associate degree college than are the children of non-academic households with 1991 income over $\$ 100,000$.

\section{Parent Education}

There is substantial evidence that parental education affects college choices [Ihlanfedlt, 1980; Rouse, 1994; Litten, 1983; and Basten, Cole Maestas, and Mason, 1997]. To establish a comparably educated benchmark group with less information about colleges and universities than faculty, we classify the NELS sample by the level of education of the most highly educated parent. Table 6 reports the proportion of children entering each Carnegie Classification from the NELS sample by the highest level of education attained by the most educated parent. ${ }^{14}$ Parents with more education are substantially more likely to have children who enter a Research Extensive university or a selective Liberal Arts college. Table 6 shows the dramatic correlation between parental education and the choice of college nationally.

\footnotetext{
${ }^{14}$ We exclude from the data those with unknown parental education and where data on parental education are missing.
} 
Table 6. College Choice by Highest Education Level Attained by Highest Educated Parent, percentages by Carnegie Classification

\begin{tabular}{lrrrrrr}
\hline \multirow{2}{*}{$\begin{array}{c}\text { Students' } \\
\text { Carnegie } \\
\text { Classification }\end{array}$} & $\begin{array}{c}\text { Some or } \\
\text { no High } \\
\text { School }\end{array}$ & $\begin{array}{c}\text { High } \\
\text { School } \\
\text { Grad }\end{array}$ & $\begin{array}{c}\text { Some } \\
\text { College }\end{array}$ & $\begin{array}{c}\text { College } \\
\text { Grad }\end{array}$ & $\begin{array}{c}\text { Master's } \\
\text { Degree }\end{array}$ & $\begin{array}{c}\text { PhD, MD, } \\
\text { advanced } \\
\text { degree }\end{array}$ \\
\hline Total count & 771 & 1400 & 2901 & 1425 & 940 & 465 \\
\hline Research Extensive & $10.7 \%$ & $15.5 \%$ & $14.8 \%$ & $27.1 \%$ & $32.1 \%$ & $42.4 \%$ \\
Doctoral & 5.8 & 4.8 & 7.0 & 9.5 & 7.6 & 7.7 \\
Master's I & 17.0 & 16.8 & 21.1 & 20.9 & 19.9 & 11.8 \\
Master's II & 0.8 & 2.8 & 2.2 & 2.4 & 2.4 & 2.0 \\
Liberal Arts & 2.7 & 2.8 & 3.1 & 6.4 & 9.8 & 10.1 \\
BA General & 2.7 & 4.2 & 4.9 & 4.4 & 4.8 & 3.1 \\
Associate & 57.2 & 51.2 & 45.2 & 26.7 & 21.2 & 22.0 \\
Other & 3.0 & 2.1 & 1.6 & 2.5 & 2.2 & 0.9 \\
\hline Total & 100.0 & 100.0 & 100.0 & 100.0 & 100.0 & 100.0 \\
\hline
\end{tabular}

Source: Authors' calculation from NELS 88.

The first column of Table 7 shows the pattern of college choice from the national sample for children of parents at least one of whom has a $\mathrm{PhD}, \mathrm{MD}$, or other advanced degree. It is compared with the pattern chosen by children of selective Liberal Arts college faculty and with the pattern chosen by the children of Research university faculty, almost all of whom hold a Ph.D. The comparison reveals that college students from households with highly educated parents, most of whom are not academics, are somewhat less likely to attend Research Extensive universities vis-à-vis the children of Liberal Arts college faculty. A chi-square test rejects the null hypothesis that the proportions are the same. The children of Liberal Arts college faculty are less likely than the children of the highly educated parents in general to enter Masters' I or Associate degree colleges. They are, however, much more likely to enter selective Liberal Arts colleges. Indeed, 9.1 percent of the children of highly educated parents enter selective Liberal Arts colleges while an 
astounding 43.7 percent of the children of Liberal Arts college faculty choose to enter Liberal Arts colleges other than the one at which their parent teaches. If their parent's employer is included, the percentage of Liberal Arts college faculty children attending a category that draws only about three percent nationally, rises to 48.6 percent!

Table 7. Colleges Chosen by Children in Non-academic Families with at Least One Parent Holding a Ph.D., M.D. or Other Advanced Degree, versus Colleges Chosen by Children of Liberal Arts College and Research University Faculty

\begin{tabular}{|c|c|c|c|c|c|c|}
\hline \multirow{2}{*}{$\begin{array}{c}\text { Students' } \\
\text { Carnegie } \\
\text { Classification }\end{array}$} & \multicolumn{6}{|c|}{ Parents' Classification } \\
\hline & $\begin{array}{c}\text { NELS: } \\
\text { PHD, MD, } \\
+\end{array}$ & percent & $\begin{array}{l}\text { Research } \\
\text { University }\end{array}$ & percent & $\begin{array}{c}\text { Liberal } \\
\text { Arts }\end{array}$ & percent \\
\hline Research Extensive & 197 & $37.9 \%$ & 1826 & $50.6 \%$ & 360 & $31.7 \%$ \\
\hline Doctoral & 36 & 6.9 & 226 & 6.3 & 72 & 6.3 \\
\hline Master's I & 55 & 10.5 & 416 & 11.5 & 79 & 7.0 \\
\hline Master's II & 9 & 1.8 & 44 & 1.2 & 16 & 1.4 \\
\hline Liberal Arts & 47 & 9.1 & 831 & 23.0 & 496 & 43.7 \\
\hline BA General & 14 & 2.8 & 55 & 1.5 & 36 & 3.2 \\
\hline Associate & 102 & 19.7 & 115 & 3.2 & 32 & 2.8 \\
\hline Other & 4 & 0.8 & 94 & 2.6 & 44 & 3.9 \\
\hline Total & 465 & 89.5 & 3,607 & 100 & 1,135 & 100 \\
\hline
\end{tabular}

Source: Authors' survey and NELS 88

Test chi-square $=324.68$; critical chi-square $(0.01,7)=18.48$ for the equality of NELS proportions and children of Research university faculty. Test chi-square $=284.96$; critical chi-square $(0.01,7)=18.48$ for the equality of NELS proportions and the proportions chosen by children of selective Liberal Arts college faculty. An additional 109 children of selective Liberal Arts college faculty and 741 children of Research university faculty attend the institution where a parent is a faculty member.

The children of Research university faculty are 4.8 times as likely to enter Liberal Arts colleges and only one-seventh as likely to enter an Associate degree college as are children of highly educated parents in general. The chi-square test rejects the null 
hypothesis that the proportions in any of the columns of Table 7 are independent of the rows. It is evident that the children of Research university faculty make dramatically different college choices than children from highly educated households in general. ${ }^{15}$

Table 8. College Choice by Parental Occupation

\begin{tabular}{lrrrrrr}
\hline \multicolumn{1}{c}{$\begin{array}{c}\text { Students' } \\
\text { Carnegie } \\
\text { Classification }\end{array}$} & Other & \multicolumn{5}{c}{ Parents' Occupation } \\
\cline { 2 - 7 } Professional & \multicolumn{3}{c}{ Professional } \\
\hline Research Extensive & 855 & $20.0 \%$ & 157 & $37.4 \%$ & 154 & $23.6 \%$ \\
Doctoral & 294 & 6.9 & 35 & 8.3 & 61 & 9.4 \\
Master's I & 827 & 19.4 & 74 & 17.6 & 137 & 21.0 \\
Master's II & 105 & 2.5 & 8 & 1.9 & 15 & 2.3 \\
Liberal Arts & 219 & 5.1 & 41 & 9.7 & 28 & 4.4 \\
BA General & 178 & 4.2 & 23 & 5.5 & 34 & 5.2 \\
Associate & 1,704 & 39.9 & 79 & 18.8 & 217 & 33.3 \\
Other & 87 & 2.0 & 4 & 0.9 & 5 & 0.8 \\
\hline Total & 4,270 & 100.0 & 421 & 100.0 & 653 & 100.0 \\
\hline Sourcenyyyyyyyyyy
\end{tabular}

Source: Authors' calculation from NELS 1988.

\section{Parental Occupation}

Although there is no strong evidence that parents' occupation in general influences college choice [Basten, Cole, Maestas, and Mason, 1997] we explore the possibility within our data set nevertheless. NELS defines two groups of professionals: Professional II includes clergy, dentist, physician, scientist, and college teacher. Because it includes college teachers, it is closest to our special sample. College faculty constitute about 19 percent of the Professional II group but NELS does not identify occupations in more detail and therefore, we cannot distinguish the college teachers from the others in the

\footnotetext{
${ }^{15}$ As an alternative, we have considered the households in NELS where at least one parent has a master's degree as a benchmark. Each group of faculty children also shows a markedly different pattern of college choice than the children in households with master's degrees. Faculty children from selective Liberal Arts colleges are dramatically more likely to choose Liberal Arts colleges and much less likely to choose
} 
Professional II group. ${ }^{16}$ Comparing the NELS Professional II set to the college faculty will then understate differences because Professional II includes college faculty. NELS Professional I includes accountant, registered nurse, engineer, librarian, social worker, and actor, but excludes schoolteacher. If either parent is in the professional II category, we classify the student in the right hand column in Table 8 . If a parent is in a Professional I occupation, we count the student in the middle column of Table 8 . The table reports the pattern of college choices for those with at least one professional parent and all others with known parental occupations. Those with Professional I parents are more likely to choose Liberal Arts colleges and Research Extensive universities and those in the Professional II group are even more likely to do so.

Table 9. College Choices of Children of Liberal Arts College and Research University Faculty Compared to the College Choices of the Children of

\section{Professionals Nationally}

\begin{tabular}{|c|c|c|c|c|c|c|}
\hline \multirow{3}{*}{$\begin{array}{c}\text { Students' } \\
\text { Carnegie } \\
\text { Classification }\end{array}$} & \multicolumn{6}{|c|}{ Parents' Occupational Classification } \\
\hline & \multirow[t]{2}{*}{$\begin{array}{l}\text { Professional } \\
\text { II in NELS }\end{array}$} & \multicolumn{3}{|c|}{$\begin{array}{c}\text { Research } \\
\text { University }\end{array}$} & \multirow{2}{*}{$\begin{array}{c}\text { Liberal } \\
\text { Arts } \\
\text { College }\end{array}$} & \multirow[b]{2}{*}{ percen } \\
\hline & & percent & & percent & & \\
\hline Research Extensive & 154 & $15.8 \%$ & 1,826 & $50.6 \%$ & 360 & $31.7 \%$ \\
\hline Doctoral & 61 & 6.3 & 226 & 6.3 & 72 & 6.3 \\
\hline Master's I & 137 & 14.1 & 416 & 11.5 & 79 & 7.0 \\
\hline Master's II & 15 & 1.5 & 44 & 1.2 & 16 & 1.4 \\
\hline Liberal Arts & 28 & 2.9 & 831 & 23.0 & 496 & 43.7 \\
\hline BA General & 34 & 3.5 & 55 & 1.5 & 36 & 3.2 \\
\hline Associate & 217 & 22.3 & 115 & 3.2 & 32 & 2.8 \\
\hline
\end{tabular}

associates degree colleges. The children of Research university faculty show this same pattern and are more likely to choose Research Extensive universities.

${ }^{16}$ Statistical Abstract of the United States 1992, Table 629 Employed Civilians by Occupation, Sex, Race, and Hispanic Origin 1983 and 1991 reports the number of persons in individual detailed occupations. "Teachers, college and university" accounts for 19 percent of the occupational categories grouped as Professional II in NELS. 


\begin{tabular}{lrrrrrr} 
Other & 5 & 33.7 & 94 & 2.6 & 44 & 3.9 \\
\hline Total & 653 & 100.0 & 3,607 & 100.0 & 1,135 & 100.0 \\
\hline
\end{tabular}

Source: Authors' survey and NELS 88

Test chi-square $=917.63$; critical chi-square $(0.01,7)=18.48$ comparing NELS percentages to Research university percentages. Test chi-square $=596.67$; critical chisquare $(0.01,7)=18.48$ comparing NELS percentages to Liberal Arts college percentages. An additional 109 children of selective Liberal Arts college faculty and 741 children of Research university faculty enrolled at the institution where a parent is a faculty member.

The pattern of college choice for children of selective Liberal Arts college faculty is compared with the pattern chosen by the children of professionals in Table 9. A chisquare test rejects the null hypothesis that the proportions are equal. The children of selective Liberal Arts college faculty are fifteen times more likely to choose a Liberal Arts college, less than one-half as likely to choose Master's I institutions, and about oneeighth as likely to choose an Associate degree college.

The pattern of college choice of the children of Research university faculty is also compared to the pattern chosen by the children of professionals nationally in Table 9. The chi-square test rejects the null hypothesis that the proportions of college types attended are the same. The children of Research university faculty are three times more likely to choose Research Extensive universities other than the employer of their parent and nearly eight times as likely to choose a Liberal Arts college than the children of professionals nationally. 
Table 10. College Choices of the Children of Households with at Least One Master's Degree by Household Income in 1991, percentages

One Parent with MA and Income is:

Students' Carnegie

Classification $\$ 50 \mathrm{~K}-\$ 75 \mathrm{~K}$ \$75K-\$100K Over $\$ 100 \mathrm{~K}$ Total over $\$ 50 \mathrm{~K}$

\begin{tabular}{lcccc}
\hline Count & 393 & 218 & 354 & 964 \\
\hline Research Extensive & $31.7 \%$ & $38.5 \%$ & $43.1 \%$ & $37.4 \%$ \\
Doctoral & 8.1 & 8.1 & 8.1 & 8.1 \\
Master's I & 21.1 & 19.4 & 11.5 & 17.2 \\
Master's II & 1.9 & 2.1 & 2.1 & 2.0 \\
Liberal Arts & 6.5 & 7.7 & 18.8 & 11.3 \\
BA General & 3.7 & 5.3 & 4.9 & 4.5 \\
Associate & 26.2 & 17.1 & 9.3 & 18.0 \\
Other & 0.9 & 1.8 & 2.3 & 1.6 \\
\hline Total & 100.0 & 100.0 & 100.0 & 100.0 \\
\hline
\end{tabular}

Source: Authors' survey and NELS 88

\section{Income and Education Together}

To allow for the possibility of interaction between income and education, we create a benchmark group of NELS households with at least one parent with a master's degree or higher and with 1991 household income exceeding $\$ 100,000$. Table 10 reports the pattern of college choice for NELS families with at least master's degrees by income level. Table 11 compares the college choice of children of faculty with children of the top income category holding masters degrees or higher. The contrasts are similar to those found earlier. Faculty children are substantially more likely to choose Liberal Arts colleges and are much less likely to choose Associate degree colleges. The benchmark group of children from highly educated families with high income choose Research Extensive universities more frequently than do the children of Liberal Arts college faculty but slightly less frequently than do the children of Research university faculty. 
Table 11. College Choices of Children of selective Liberal Arts College and

Research University Faculty compared to the College Choices of the Children of

Households with at Least One Master's Degree and Household Income over $\$ 100,000$ in 1991

\begin{tabular}{lcccccc}
\hline & \multicolumn{6}{c}{ Parents' Classification } \\
\cline { 2 - 7 } \multicolumn{1}{c}{$\begin{array}{c}\text { Students' } \begin{array}{c}\text { High } \\
\text { Carnegie }\end{array} \\
\text { Classification }\end{array}$} & $\begin{array}{c}\text { Education } \\
\text { \& Income }\end{array}$ & $\begin{array}{c}\text { Research } \\
\text { University }\end{array}$ & \multicolumn{3}{c}{$\begin{array}{c}\text { Liberal } \\
\text { Arts }\end{array}$} \\
\hline perearch Extensive & 152 & $43.1 \%$ & 1,826 & $50.6 \%$ & 360 & $31.7 \%$ \\
Doctoral & 29 & 8.1 & 226 & 6.3 & 72 & 6.3 \\
Master's I & 41 & 11.5 & 416 & 11.5 & 79 & 7.0 \\
Master's II & 7 & 2.1 & 44 & 1.2 & 16 & 1.4 \\
Liberal Arts & 66 & 18.8 & 831 & 23.0 & 496 & 43.7 \\
BA General & 17 & 4.9 & 55 & 1.5 & 36 & 3.2 \\
Associate & 33 & 9.3 & 115 & 3.2 & 32 & 2.8 \\
Other & 8 & 2.3 & 94 & 2.6 & 44 & 3.9 \\
\hline Total & 354 & 100.0 & 3,607 & 100.0 & 1,135 & 100.0 \\
\hline
\end{tabular}

Source: Authors' survey and NELS 88 .

Test chi-square $=62.93$; critical chi-square $(0.01,7)=18.48$ comparing NELS

percentages to Research university percentages. Test chi-square $=93.78$; critical chisquare $(0.01,7)=18.48$ comparing NELS percentage to selective Liberal Arts college percentages. An additional 109 children of selective Liberal Arts college faculty and 741 children of Research university faculty attend the institution where a parent is a faculty member.

\section{Regional Weighting}

Our opportunistic sample of 16 colleges and nine universities includes many more colleges and universities in the northeast than would be found in a random national sample. Private colleges, particularly selective Liberal Arts colleges, are more common in the northeast. Two-year (Associate degree) colleges are significantly more common in California, Texas, and Florida and are less common in the northeast. Although the role 
of distance in college choice is waning [Long, 2003], it remains true that students are more likely to attend colleges that are closer to home. [Litten, 1988; Long, 2003] To allow for the possibility of regional influences, we count the number of faculty children in each census region in our sample and weight the households in NELS who have incomes over $\$ 100,000$ and at least one master's degree by the weight of the regions in our sample. The results are reported in Table 12. The differences in patterns noted in each of the earlier comparisons persist, albeit with somewhat less intensity. In this comparison, the children of selective Liberal Arts college faculty are only twice as likely to attend a Liberal Arts college than are children from households of comparable regions with masters degrees or above and household income over $\$ 100,000$.

Table 12. Comparison to College Choice of the Children of Households with at Least One Master's Degree and Household Income over \$100,000 in 1991 with Regional Weights

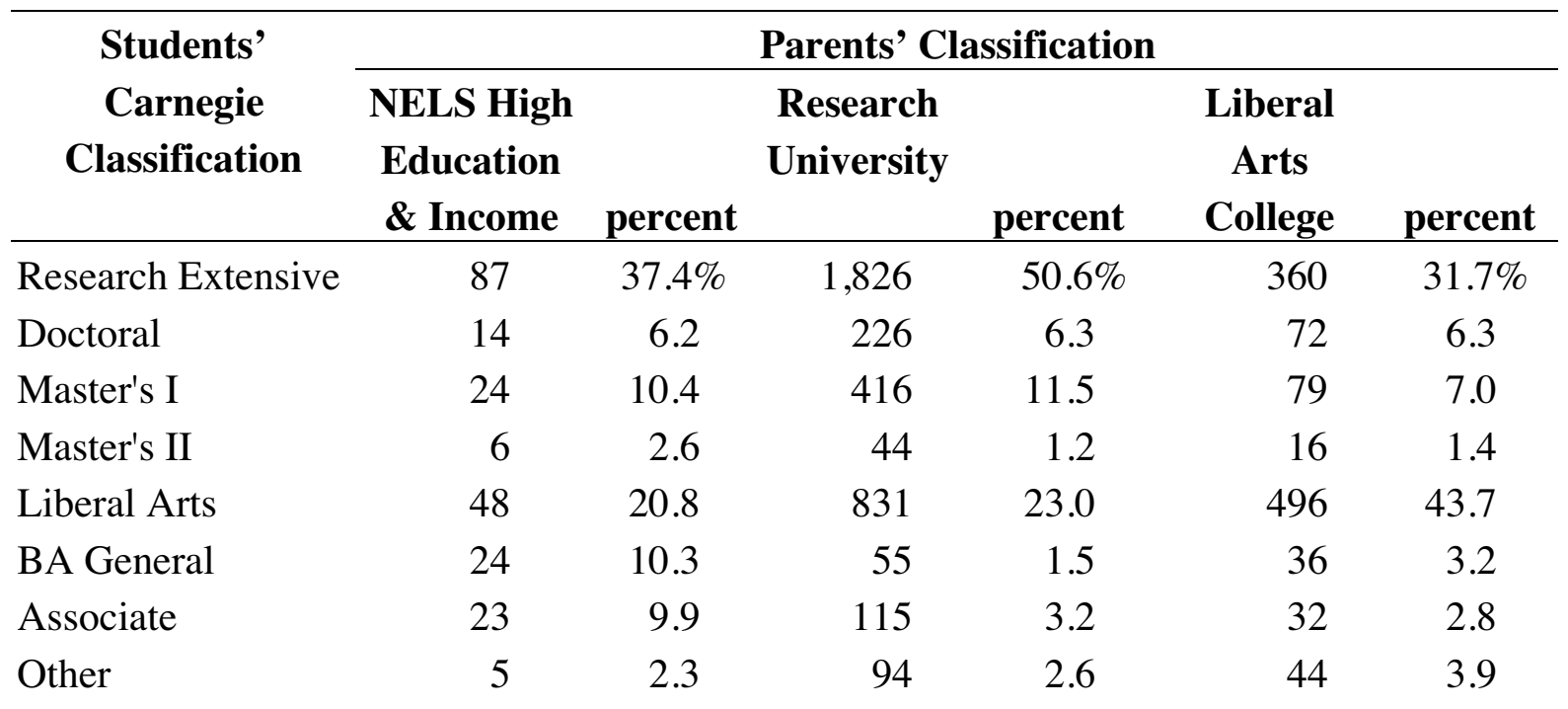




\begin{tabular}{lllllll}
\hline Total & 232 & 100.0 & 3,607 & 100.0 & 1,135 & 100.0 \\
\hline
\end{tabular}

Source: Authors' survey and NELS 88

Test chi-square $=121.29 ;$ critical chi-square $(0.01,7)=18.48$ comparing NELS

percentages to Research university percentages. Test chi-square $=79.82$; critical chisquare $(0.01,7)=18.48$ comparing NELS percentages to selective Liberal Arts college

percentages. An additional 109 children of selective Liberal Arts college faculty and 741 children of Research university faculty attend the institution where a parent is a faculty member.

\section{Staff}

Our survey also generated information about the college attended by the children of college and university staff. We expect staff to have more information about colleges and universities than the public in general, but less than is available to families in comparable socio-demographic circumstances that contain a faculty member. Thus we expect the distribution of college types chosen by children of staff to fall between those of faculty and the public at large. We compare the pattern of colleges chosen by the children of staff to the pattern chosen by households with 1991 income between $\$ 15,000$ and $\$ 35,000 .{ }^{17}$ Table 13 makes a simple comparison and Table 14 applies regional weights reflecting the census regions of children of staff in our survey. With and without regional weights, the children of staff display a different pattern of college choice than

\footnotetext{
${ }^{17}$ The Bureau of Labor Statistics, Median Usual Weekly Earnings for Full-time and Salaried Workers by Occupation, Fourth Quarter 1991 reports a weekly wage of $\$ 365$ for “Administrative support, including clerical that includes office supervisors, secretaries, library clerks, mail clerks, computer operators, and others." Assuming 52 weeks per year puts the annual rate $\$ 18,980$.
} 
Table 13. College Choices of Children of Liberal Arts College and Research University Staff compared to the College Choices of Children of Households with Income from $\$ 15,000$ to $\$ 35,000$ in 1991.

\begin{tabular}{|c|c|c|c|c|c|c|}
\hline \multirow{4}{*}{$\begin{array}{c}\text { Students' } \\
\text { Carnegie } \\
\text { Classification }\end{array}$} & \multicolumn{6}{|c|}{ Parents' Classification } \\
\hline & \multirow{3}{*}{$\begin{array}{l}\text { NELS } \\
\$ 15 \text { to } \\
\$ 35 \mathrm{~K} \\
\end{array}$} & \multirow{3}{*}{\multicolumn{2}{|c|}{$\begin{array}{c}\text { Research } \\
\text { University } \\
\text { nt }\end{array}$}} & \multirow{3}{*}{\multicolumn{2}{|c|}{$\begin{array}{c}\text { Liberal } \\
\text { Arts } \\
\text { College } \\
\end{array}$}} & \multirow[b]{3}{*}{ percen } \\
\hline & & & & & & \\
\hline & & & & & & \\
\hline Research Extensive & 261 & $15.5 \%$ & 2,493 & $28.3 \%$ & 354 & $22.7 \%$ \\
\hline Doctoral & 109 & 6.5 & 1,020 & 11.6 & 77 & 4.9 \\
\hline Master's I & 325 & 19.3 & 2,310 & 26.2 & 352 & 22.6 \\
\hline Master's II & 36 & 2.1 & 233 & 2.6 & 48 & 3.1 \\
\hline Liberal Arts & 51 & 3.0 & 897 & 10.2 & 300 & 19.3 \\
\hline BA General & 98 & 5.8 & 317 & 3.6 & 75 & 4.8 \\
\hline Associate & 776 & 46.0 & 1,274 & 14.4 & 300 & 19.3 \\
\hline Other & 29 & 1.7 & 276 & 3.1 & 51 & 3.3 \\
\hline Total & 1,686 & 100.0 & 8,820 & 100.0 & 1,557 & 100.0 \\
\hline
\end{tabular}

Source: Authors' survey and NELS 1988.

Test chi-square $=980.26$; critical chi-square $(0.01,7)=18.48$ compares NELS percentages to Research university percentages. Test chi-square $=414.38$; critical chisquare $(0.01,7)=18.48$ compares NELS percentages to selective Liberal Arts college percentages. An additional 123 children of selective Liberal Arts college staff and 847 children of Research university staff attend the institution where a parent is a faculty member.

the NELS comparison group. The children of selective Liberal Arts college staff are significantly more likely to choose to attend Liberal Arts colleges and are much less likely to attend a two-year college. The same differences hold for the staff of Research universities. While the proportion of staff children selecting Research Extensive universities is about the same as the benchmark, the proportion selecting Liberal Arts 
colleges greatly exceeds the benchmark. The children of Liberal Arts college staff are more than seven times more likely to choose a Liberal Arts college than the benchmark group in NELS and the children of Research university staff are more than three times as likely to choose a Liberal Arts college.

Table 14. College Choices of Children of Liberal Arts College and Research University Staff Compared to the College Choices of Children of Households with Income in 1991 from $\$ 15,000$ to $\$ 35,000$, with Regional Weights

\begin{tabular}{|c|c|c|c|c|c|c|}
\hline \multirow{2}{*}{$\begin{array}{c}\text { Students' } \\
\text { Carnegie } \\
\text { Classification }\end{array}$} & \multicolumn{6}{|c|}{ Parents' Classification } \\
\hline & $\begin{array}{c}\text { NELS } \\
\$ 15,000 \text { to } \\
\$ 35,000\end{array}$ & percent & $\begin{array}{c}\text { Research } \\
\text { University }\end{array}$ & percent & $\begin{array}{c}\text { Liberal } \\
\text { Arts } \\
\text { College }\end{array}$ & percent \\
\hline Research Extensive & 112 & $16.2 \%$ & 2,493 & $28.3 \%$ & 354 & $22.7 \%$ \\
\hline Doctoral & 58 & 8.4 & 1,020 & 11.6 & 77 & 4.9 \\
\hline Master's I & 106 & 15.3 & 2,310 & 26.2 & 352 & 22.6 \\
\hline Master's II & 24 & 3.5 & 233 & 2.6 & 48 & 3.1 \\
\hline Liberal Arts & 18 & 2.6 & 897 & 10.2 & 300 & 19.3 \\
\hline BA General & 29 & 4.2 & 317 & 3.6 & 75 & 4.8 \\
\hline Associate & 334 & 48.3 & 1,274 & 14.4 & 300 & 19.3 \\
\hline Other & 10 & 1.4 & 276 & 3.1 & 51 & 3.3 \\
\hline Total & 691 & 100.0 & 8,820 & 100.0 & 1,557 & 100.0 \\
\hline
\end{tabular}

Source: Authors' survey and NELS 1988.

Test chi-square $=551.88$; critical chi-square $(0.01,7)=18.48$ compares NELS percentages to Research university staff children percentages. Test chi-square $=$ 275.79; critical chi-square $(0.01,7)=18.48$ compares NELS percentages to selective Liberal Arts college percentages. An additional 123 children of selective Liberal Arts college staff and 847 children of Research university staff attend the institution where a parent is a faculty member. 


\section{Conclusions}

The children of college and university faculty make dramatically different choices among colleges and universities than do children from non-academic households with similar incomes, occupations, and education. The evidence supports the first element of the Zemsky-Massy hypothesis: Better-informed consumers do make markedly different college choices.

With regard to the second part of the hypothesis, the evidence is mixed and ultimately difficult to interpret. The better-informed consumers choose more selective, prestigious colleges and universities, primarily private Research Extensive universities and selective Liberal Arts colleges. On its face, this suggests that the prestige sought by the public at large is even more valuable to college and university faculty. The insiders choose the expensive colleges and universities. Of course, well-educated parents are also more likely to serve as role models that promote a culture of achievement in their children [Basten, Cole, Maestas, and Mason, 1997], which may be what is reflected in the college choices of our sample of faculty children.

There is a substantial tilt toward liberal arts colleges among the choices. Because of their small scale, more modest emphasis on athletics as a public spectacle, and lower research profile, the liberal arts colleges do not garner the press, television exposure, and national name-recognition enjoyed by the nation's premier research universities. Yet, in comparison to well-educated high-income families in general, the children of the insiders are many times more likely to choose a liberal arts college. That the children of research university faculty also are substantially more likely to attend liberal arts 
colleges than the public at large indicates that there are forces at work beyond children simply choosing familiar institutions like those where a parent works.

With regard to the second part of the hypothesis, the evidence is mixed and ultimately difficult to interpret. The better-informed consumers choose more selective, prestigious colleges and universities, primarily private Research Extensive universities and selective Liberal Arts colleges. On its face, this suggests that the prestige sought by the public at large is even more valuable to college and university faculty. The insiders choose the expensive colleges and universities. Of course, well-educated parents are also more likely to serve as role models that promote a culture of achievement in their children [Basten, Cole, Maestas, and Mason, 1997], which may be what is reflected in the college choices of our sample of faculty children.

There is a substantial tilt toward liberal arts colleges among the choices. Because of their small scale, more modest emphasis on athletics as a public spectacle, and lower research profile, the liberal arts colleges do not garner the press, television exposure, and national name-recognition enjoyed by the nation's premier research universities. Yet, in comparison to well-educated high-income families in general, the children of the insiders are many times more likely to choose a liberal arts college. That the children of research university faculty also are substantially more likely to attend liberal arts colleges than the public at large indicates that there are forces at work beyond children simply choosing familiar institutions like those where a parent works.

One explanation of the dominant role for liberal arts colleges among faculty children may be that insiders recognize that, consistent with the argument of Zemsky and Massy, 
liberal arts colleges place more emphasis on teaching undergraduates than do research universities. One indication of this emphasis is the relatively higher teaching load for faculty at liberal arts colleges. Clotfelter [1996] shows the difference between annual course loads by discipline for three research universities and one liberal arts college, revealing much higher loads in the liberal arts college. For example, the typical faculty member in a social science department at Carleton College taught five courses per year in 1991-92, compared to three courses per year at the University of Chicago, only one of which was for undergraduates. The National Study of Postsecondary Faculty 1999 shows a median load of two courses for the fall term for research universities and three courses for liberal arts colleges. ${ }^{18}$ With graduate education comprising a significant part of teaching responsibilities at research universities, the teaching effort per faculty member devoted to undergraduates is typically much greater at liberal arts colleges than at research universities. At the most selective liberal arts colleges, faculty commitment to research and publication is significant. [McCaughey, 1994] A survey of faculty at selective liberal arts colleges showed that 90 percent viewed publication as an essential job responsibility, a figure that compares well with 94 percent at research universities..$^{19}$ Yet, 63 percent of liberal arts college faculty "believed teaching effectiveness should be the primary criterion for promoting faculty" while 69 percent of "university respondents agreed it should not." In both effort and emphasis, the faculty at liberal arts colleges do considerably more teaching of undergraduates than do the faculty of research

\footnotetext{
${ }^{18}$ Authors' calculation from National Center for Education Statistics, National Study of Postsecondary Faculty 1999.

${ }^{19}$ McCaughey makes clear (page 82) that faculty at liberal arts colleges in the northeast in closer proximity to research universities produce more publications than faculty at liberal arts colleges more remote from research universities. Not all liberal arts colleges perform the same. McCaughey doesn't identify the colleges by level of publication and so we cannot judge whether faculty children choose those where faculty do more publishing.
} 
universities. And, of course, there are few classes taught by inexperienced graduate student teaching assistants at selective liberal arts colleges.

Another possible explanation for the dramatic differences in college choices is that the faculty children attend undergraduate institutions similar to the undergraduate institutions attended by their parents. McCaughey [1994] reports that of the top twenty colleges and universities with the highest proportion of baccalaureate degree holders receiving $\mathrm{PhDs}$, sixteen are selective liberal arts colleges. ${ }^{20}$ The number one college for rate of baccalaureate degree holders earning a Ph.D. is Byrn Mawr at 6.1 percent; Chicago is fourth at 4.2 percent; Pomona is tenth at 3.7 percent; Yale and Harvard are thirteenth and fourteenth at 3.1 percent. To assess the possibility that the children of faculty pursue higher education at the type of institution where the parent entered college, we consider the pattern of undergraduate institution attended by faculty at three of the research universities in our survey. Table 15 shows that indeed, 62.1 percent of faculty at research universities who earned undergraduate degrees in the United States at institutions other than where they are currently employed attended research universities as undergraduates. Fourteen percent attended liberal arts colleges. The table shows that the children of research university faculty are less likely to choose both research universities and liberal arts colleges than their parents. Indeed, a child is only 45 percent as likely to attend a research university and only 70 percent as likely to attend a liberal arts college as the parents. Although the children of research university faculty are less

\footnotetext{
${ }^{20}$ Robert A. McCaughey, Scholars and Teachers: The Faculty of Select Liberal Arts Colleges and Their Place in American Higher Education, (New York: McCaughey with a grant from the Mellon Foundation, 1994) p. 94 and table p. 110.. PhDs in the humanities and social sciences $1980-89$ by average number of ABs $1970-1979$. The rate of Ph.D. earning B.A.s is greatest among the liberal arts colleges where faculty do more research.
} 
likely to enter highly selective institutions as their parents, the tilt toward liberal arts colleges remains.

The educational experience of faculty parents also bears on the observed differences in college choices between those children of Research university faculty and those with a parent who teaches at a selective Liberal Arts college. Perhaps more revealing than the fact that so many children of Liberal Arts college faculty matriculate at a Liberal Arts college is the extent of "crossovers." After the predominant choice of "own-type" of institution, the two crossover choices - children of Research university faculty selecting Liberal Arts colleges and children of Liberal Arts college faculty choosing to attend a Research university — are a strong second choice. Because virtually all of them hold a Ph.D., all faculty at selective liberal arts colleges will have personal experience as a graduate student and many as a teaching assistant at a Research university. The converse, however, does not hold. Faculty at Research universities need not have had personal experience with a Liberal Arts college. If personal life experience of a parent were the guide, the tilt would be toward Research universities and not toward Liberal Arts colleges. 
Table 15. The Undergraduate Alma Maters of Research University Faculty

\begin{tabular}{|c|c|c|c|c|c|c|}
\hline $\begin{array}{c}\text { Carnegie } \\
\text { Classification }\end{array}$ & $\begin{array}{l}\text { Parent's } \\
\text { Undergradu- } \\
\text { ate Alma } \\
\text { Mater }\end{array}$ & percent & $\begin{array}{c}\text { Choice of } \\
\text { Children } \\
\text { of } \\
\text { Research } \\
\text { University }\end{array}$ & percent & $\begin{array}{c}\text { Choice of } \\
\text { Children of } \\
\text { Liberal } \\
\text { Arts } \\
\text { College } \\
\end{array}$ & percent \\
\hline Research Extensive & 448 & $62.1 \%$ & 2,493 & $28.3 \%$ & 354 & $22.7 \%$ \\
\hline Doctoral & 60 & 8.3 & 1,020 & 11.6 & 77 & 4.9 \\
\hline Master's I & 72 & 10.0 & 2,310 & 26.2 & 352 & 22.6 \\
\hline Master's II & 13 & 1.8 & 233 & 2.6 & 48 & 3.1 \\
\hline Liberal Arts & 102 & 14.1 & 897 & 10.2 & 300 & 19.3 \\
\hline BA General & 11 & 1.5 & 317 & 3.6 & 75 & 4.8 \\
\hline Associate & 4 & 0.6 & 1,274 & 14.4 & 300 & 19.3 \\
\hline Other & 11 & 1.5 & 276 & 3.1 & 51 & 3.3 \\
\hline 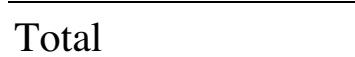 & 721 & 0.0 & 820 & 00.0 &, 557 & 00.0 \\
\hline
\end{tabular}

Source: Authors' calculation from systematic random samples from published documents (choosing every seventh faculty member in alphabetic order with a randomly chosen starting point from one to seven) and faculty websites from Cornell, Johns Hopkins, and Vanderbilt. We identified the undergraduate institution for 98 percent of our sample at Vanderbilt, 37 percent of the sample at Cornell, and 57 percent of the sample at Johns Hopkins. The table omits 83 faculty who work at their undergraduate alma maters ( 8.5 percent of the total) and 184 who earned undergraduate degrees abroad (16.8 percent). Where a faculty member earned a foreign graduate degree but did not report an undergraduate institution, we assume an undergraduate degree was earned abroad. The chi-square test to compare the Research university faculty's undergraduate college with their children's choice is 446.2. The chi-square comparing the pattern of choice of the children of Liberal Arts college faculty with the pattern of undergraduate institution of Research university faculty is 428.1 .

The faculty at the selective liberal arts colleges earned their Ph.D.s at quite a small number of research universities: Harvard, 12 percent: Yale, ten percent: and Columbia, seven percent: with Princeton, Chicago, Berkeley, Stanford, Michigan, and Wisconsin adding a cumulative 23 percent more. [McCaughey, 1994] Likewise, there are likely to be significant personal connections between the faculty of Research universities and the 
selective Liberal Arts colleges, both as the source of parent undergraduate degrees and colleges where former graduate students are employed.

McCaughey [1994] describes changes occurring in selective liberal arts colleges that may make them more attractive to research university faculty who may transmit that attitude to their children. Although the liberal arts colleges retain their relatively smaller size and focus on undergraduate education, the more selective among them are growing modestly in size, hiring fewer of their own graduates as faculty, putting more emphasis on faculty research and publication, and reducing teaching loads to encourage faculty scholarship. They are not transforming themselves into research universities, but they are recruiting both faculty and students more widely and recognizing that active scholarship often interacts positively with good teaching. The liberal arts colleges may be reinventing themselves in ways that faculty at liberal art colleges themselves and research universities as well find appealing for their children.

Ultimately, there may be other reasons as to why the children of college and university faculty behave differently than children in similarly situated non-academic households. In addition to the income and price effects of the tuition remission benefit mentioned at the outset, faculty are likely to place a high value on education, reading, speaking, and discussion. As a consequence, their home life may develop skills and expectations in children that differ from others, especially an appreciation for education that is not particularly career-oriented. [Litten, 1988] They may make different decisions about elementary and secondary education that eventually have consequences for college choices. The children of faculty may develop different career goals. Indeed, when academic credentials are similar, colleges may prefer to admit the children of faculty for their intellectual orientation. Our study is unable to distinguish among these alternative 
causes of the differences in behavior. We believe, however, that we have documented remarkable differences between the choices of college by the children of faculty at research universities and liberal arts colleges, and the rest of the population in similar socio-demographic circumstances. 


\section{References}

Basten, Jay, John Cole, Ricardo Maestas, Katherine Mason. "Redefining the Virtuous Cycle" Replacing the Criterion of Race with Socioeconomic Status in the Admissions Process in Highly Selective Institutions." Presented at the annual meeting of the Association for the Study of Higher Education, Albuquerque, New Mexico, November, 1997.

Bateman, Mark, and Eugene Kennedy. "Expanding the Applicant Pool: Exploring the College Decision-Making of Students from Single-Parent Families.” Journal of the American Association of Collegiate Registrars and Admissions Officers. 75 \#1 (Summer, 1999) pp. 2-10.

Cabrera, Alberto F., and Steven M. La Nasa, Understanding the College Choice of Disadvantaged Students," (San Francisco: Jossey-Bass) \#107 Fall 2000.

Cappelli, Peter. "Why do Employers Pay for College?” (Cambridge, MA: National Bureau of Economic Research, 2002) Working Paper \#9225

Ceja, Miguel. "Making Decisions about College: Understanding the Information Sources of Chicano Students," Higher Education Research Institute, Graduate School of Education and Information Studies, University of California-Los Angeles. Paper presented at the Annual Meeting of the Association for the Study of Higher Education, Sacramento, California, November 2000.

Clotfelter, Charles T., Buying the Best (Princeton: Princeton University Press, 1996) Chapter 7.

Hossler, Don and Frances K. Stage. "Family and High School Experience Influences on the Post-secondary Educational Plans of Ninth Grade Students." American Educational Research Journal. 29 \#2 (Spring. 1987) pp. 425-51.

Ihlandfeldt, William. Achieving Optimal Enrollments and Tuition Revenues (San Francisco: Jossey-Bass) 1980. 
King, Jacqueline E. "The Decision to Go to College: Attitudes and Experiences Associated with College Attendance Among Low-Income Students." The College Board (1996).

Litten, Larry. "A General Perspective on Preferences and Choices in College Selection," Chapter 4 in Applying Market Research in College Admissions. (New York: College Entrance and Examination Board) 1983.

Long, Bridget Terry. "How Have College Decisions Changed Over Time? An Application of the Conditional Logistic Choice Model." unpublished manuscript, Harvard Graduate School of Education, (January 2003).

Manski, Charles F., and David A.Wise, College Choice in America (Cambridge, MA: Harvard University Press, 1983).

McCaughey, Robert A. Scholars and Teachers: The Faculty of Select Liberal Arts Colleges and Their Place in American Higher Education, (New York: McCaughey with a grant from the Mellon Foundation, 1994).

Monks, James; Ronald G. Ehrenberg. “The Impact of U.S. News \& World Report College Rankings on Admission Outcomes and Pricing Decisions at Selective Private Institutions," National Bureau of Economic Research Working Paper 7227, July 1999.

Moogan, Yvonne, Steve Baron, and Kim Harris. "Decision-Making Behavior of Potential Higher Education Students.” Higher Education Quarterly 53 \#3 (July 1999) pp. 211-28.

Paulson, Michael B. and Edward P. St. John. "Social Class and College Costs." The Journal of Higher Education 73 \#2 (March/April 2002). pp. 189-236.

Rouse, Cecelia E. "What to Do After High School: The Two-year versus Four-year College Enrollment Decision.” Chapter 4 in Ronald G. Ehrenberg, Choices and Consequences (Ithaca, New York: ILR Press) 1994 pp. 59-88.

Spies, Richard R. "The Effect of Rising Costs on College Choice," (New York: College Entrance Examination Board, 1978). 
Toutkoushian, Robert K. "Do Parental Income and Educational Attainment Affect the Initial Choices of New Hampshire's College Bound Students?” Economics of Education Review, 20 \#3 (June 2001) pp. 245-62.

Zemsky, Robert, William Massy, Daniel Shapiro, Susan Shaman, Gregers Dubrow, and Giancola, Jennifer. Market, Price and Margin: Determining the Cost of an Undergraduate Education (Philadelphia: Institute for Research on Higher Education, University of Pennsylvania, 1999). 


\section{Appendix A: Terms of Portable Tuition Remission Benefit for Children of Faculty and Staff at Twenty-five Universities and Colleges that Participated in the Survey. \\ Summary of Benefits for Faculty}

\begin{tabular}{|c|c|c|c|c|c|}
\hline UNIVERSITIES & Vesting & Benefit/yr & Ceiling & Staff & Notes \\
\hline 1 Brown & 4 years & $\$ 10,000$ & $\$ 10,000$ & none & Prior to $1979,100 \%$ Brown tuition limit \\
\hline 2 Carnegie Mellon & full & $\$ 3,700$ & $\$ 3,700$ & $5 \mathrm{yrs}$ & $100 \%$ at $\mathrm{CMU}$ \\
\hline 3 Clark & 5 years & $60 \%$ & $60 \%$ of $\mathrm{CU}$ & same & \\
\hline 4 Cornell & 4 years & $30 \%$ & $30 \%$ of $\mathrm{CU}$ & same & employed after 1985 \\
\hline 5 Johns Hopkins & 2 years & $50 \%$ & $50 \%$ of JHU & same & \\
\hline $6 \mathrm{MIT}$ & full & $50 \%$ & $50 \%$ of MIT & none & $100 \%$ at MIT \\
\hline 7 Vanderbilt & 5 years & $70 \%$ & $70 \%$ of $\mathrm{VU}$ & same & $100 \%$ if tuition under $\$ 2,857$ \\
\hline 8 Yale & 6 years & $50 \%$ & $\$ 10,700$ & same & at 4 year colleges only \\
\hline 9 Washington. & 7 years & $50 \%$ & $50 \%$ of WU & same & $100 \%$ at Washington University, St Louis \\
\hline $\begin{array}{l}\text { LIBERAL ARTS } \\
\text { COLLEGES }\end{array}$ & & & & & \\
\hline 1 Amherst & full & $\$ 4,000$ & $\$ 4,000$ & same & \\
\hline 2 Bryn Mawr & 7 years & $50 \%$ & $50 \%$ of $\mathrm{BM}$ & same & $2 \mathrm{sem}$. for each year over $7,16 \mathrm{sem}$. max \\
\hline 3 Claremont & 2 years & $50 \%$ & $50 \%$ of $\mathrm{CC}$ & same & \\
\hline 4 Colby & 6 years & $50 \%$ & $50 \%$ of $\mathrm{CC}$ & $38.1 \%$ & \\
\hline 5 Davidson & 7 years & $50 \%$ & $50 \%$ of DC & same & \\
\hline 6 Gettysburg & 2 years & $30 \%$ & $30 \%$ of GC & same & $100 \%$ at $\mathrm{GC}$ \\
\hline 7 Hamilton & 3 years & $50 \%$ & $50 \%$ of $\mathrm{HC}$ & same & $100 \%$ at $\mathrm{HC}$ \\
\hline 8 Lafayette & full & $100 \%$ & $100 \%$ & same & Phased to $50 \%$ after $1979 ; 3$ years vesting \\
\hline 9 Middlebury & 4 years & $45 \%$ & $45 \%$ of $\mathrm{MC}$ & same & with 10 years service, $50 \%$ to $30 \%$ of $\mathrm{MC}$ \\
\hline 10 Pomona & 1 year & $50 \%$ & $50 \%$ of PC & same & \\
\hline 11 Smith & full & $40 \%$ & $40 \%$ of SC & same & $60 \%$ at Smith, Tuition Exchange also \\
\hline 12 Swarthmore & 5 years & $50 \%$ & $\$ 10,580$ & same & \\
\hline 13 Trinity & 5 years & $50 \%$ & $50 \%$ of TC & limited & high level staff only \\
\hline 14 Union & 5 years & $50 \%$ & $50 \%$ of UC & same & $100 \%$ at $\mathrm{UC}$ \\
\hline 15 Wesleyan & full & $50 \%$ & \multicolumn{3}{|c|}{$50 \%$ of WC 25 or $35 \%$} \\
\hline 16 Williams & 5 years & $50 \%$ & $50 \%$ ofWC & same & \\
\hline
\end{tabular}

\section{Definitions:}

Vesting: Number of years of employment required for eligibility. Full means immediate vesting. Terms of plans are usually defined by the year of employment. 
Benefits/year: Dollars of tuition remission per year or percentage of tuition remitted.

Ceiling: Maximum benefit in dollars or as percentage of home tuition.

Staff: Same means staff get same benefit; percentage if staff rate differs.

None means no staff benefit.

Notes: Other features or limits on tuition remission benefit. 


\section{Appendix B. Summary of Survey of Liberal Arts Colleges and Universities}

\begin{tabular}{|c|c|c|c|c|}
\hline \multirow[b]{2}{*}{ UNIVERSITIES } & \multicolumn{4}{|c|}{ Number of Children with Reported College Attended } \\
\hline & Faculty & Administration & Staff & Range of Years \\
\hline 1Brown & 71 & - & 170 & NA \\
\hline 2Carnegie Mellon & 84 & - & - & NA \\
\hline 3Clark & 106 & - & 271 & 1992-00 (omitting 96-97) \\
\hline 4Cornell & 598 & - & 1,055 & 1992-01 \\
\hline 5Johns Hopkins & 874 & 74 & 2,132 & NA \\
\hline $6 \mathrm{MIT}$ & 415 & - & 1,375 & NA \\
\hline 7Vanderbilt & 928 & - & 2,061 & $1991-00$ \\
\hline 8 Yale & 479 & - & 1,148 & $1991-00$ \\
\hline 9Washington University & 793 & - & 1,456 & NA \\
\hline Total Universities & 4,348 & 74 & 9,668 & \\
\hline
\end{tabular}

\begin{tabular}{|c|c|c|c|c|}
\hline 1Amherst & 58 & - & 88 & $1992-00$ \\
\hline 2Bryn Mawr & 46 & - & 43 & 1992-02 \\
\hline 3Claremont & 14 & - & 23 & 1990-02 \\
\hline 4Colby & 62 & 61 & 71 & NA \\
\hline 5Davidson & 57 & - & 143 & 1991-01 \\
\hline 6Gettysburg & 89 & 68 & 86 & 1991-01 \\
\hline 7Hamilton & 52 & 51 & 24 & $1991-00$ \\
\hline 8Lafayette & 58 & 28 & 75 & NA \\
\hline 9Middlebury & 263 & - & 372 & NA \\
\hline 10Pomona & 124 & - & 214 & 1990-01 \\
\hline 11Smith & 97 & 95 & 116 & 1996-01 \\
\hline 12Swarthmore & 25 & - & 84 & NA \\
\hline 13Trinity & 72 & 18 & - & NA \\
\hline 14Union & 76 & 38 & 143 & NA \\
\hline 15Wesleyan & 89 & 117 & 56 & 1999-01 \\
\hline 16Williams & 62 & - & 142 & 1994-02 \\
\hline Total Liberal Arts Colleges & 1,244 & 476 & 1,680 & \\
\hline Grand Total & 5,592 & 550 & 11,347 & \\
\hline
\end{tabular}


Note: In some cases, institutions supplied partial records for certain years. In most cases, the institutions reported the first college attended. 


\section{Appendix C. Alternate Chi-square Tests}

The chi-square tests reported in the essay compare proportions across eoght Carnegie Classifications and are repeated here in the first column.

To view the choice among the regular four-year colleges as the critical choice set, compare proportions across the top eight Carnegie Classifications, omitting the Associate and Other classifications. The chi-square test considering only the eight regular four-year classifications appear in the second column.

Take the Research Extensive and Liberal Arts as two classes. Aggregate the other four regular four-year Carnegie Classifications into a third set, so that changes in proportions among the four do not influence the test. This test appears in the third column.

\section{Research \\ Extensive,}

\section{All Eight Carnegie Four-Year Set of Liberal Arts, and} Comparison: Classifications

\begin{tabular}{lccr}
\hline Number of categories & \multicolumn{2}{l}{6} & \multicolumn{2}{l}{$\begin{array}{l}\text { 8 } \\
\text { Critical Values }(\mathrm{a}=0.01)\end{array}$} & 18.48 & 15.09 & 9.21 \\
\hline
\end{tabular}

Table 2

Faculty Children versus Staff Children

$$
1775.93 \quad 1240.25
$$

Table 3

Children of Research Univ. v Children of Liberal Arts

$$
233.57
$$

229.48

202.65

Table 5

NELS income over $\$ 50 \mathrm{~K}$ versus

children of Research

174.57

55.78

39.44

children of Liberal Arts

213.13

141.60

138.42

Table 7

NELS parent with $\mathrm{PhD}$ versus

children of Research

324.68

39.59

32.29

children of Liberal Arts

284.96

132.11

128.51

Table 9

NELS parent in Professional

children of Research

917.63

285.05

266.06

children of Liberal Arts

Table 11

596.67

304.17

289.39

NELS parent income over $\$ 100 \mathrm{~K}$ and MA or more

children of Research

62.93

30.82

$11.28 *$

children of Liberal Arts

Table 12

93.78

66.87

65.87

NELS Parent income over \$100K and MA, regional weights

children of Research

121.29

99.09

16.53

children of Liberal Arts

Table 13

79.82

56.26

41.56

NELS parent income $\$ 15 \mathrm{~K}$ to $\$ 35 \mathrm{~K}$ versus Staff

children of Research

980.26

114.53

52.34 
children of Liberal Arts

414.38

155.73

144.28

Table 14

NELS Parent income $\$ 15 \mathrm{~K}$ to $\$ 35 \mathrm{~K}$ versus Staff, regional wghts

children of Research 551.88

41.74

19.42

children of Liberal Arts

275.79

91.65

66.72

* Statistically significant at the 0.05 level. All others are significant at the 0.001 level of significance. 